\title{
Article \\ Solvent-Induced Hysteresis Loop in Anionic Spin Crossover (SCO) Isomorph Complexes
}

\author{
Emmelyne Cuza $^{1}$, Samia Benmansour ${ }^{2}{ }^{\circledR}$, Nathalie Cosquer ${ }^{1}$, Françoise Conan ${ }^{1}\left(\mathbb{D}\right.$, Carlos J. Gómez-García ${ }^{2, *(\mathbb{D}}$ \\ and Smail Triki ${ }^{1, *(1)}$ \\ 1 Univ Brest, CNRS, CEMCA, 6 Avenue Le Gorgeu, C.S. 93837, CEDEX 3, 29238 Brest, France; \\ Emmelyne.Cuza@univ-brest.fr (E.C.); nathalie.cosquer@univ-brest.fr (N.C.); \\ Francoise.Conan@univ-brest.fr (F.C.) \\ 2 Instituto de Ciencia Molecular (ICMol), Departamento de Química Inorgánica, Universidad de Valencia, \\ C/Catedrático José Beltrán 2, 46980 Paterna, Spain; sam.ben@uv.es \\ * Correspondence: carlos.gomez@uv.es (C.J.G.-G.); smail.triki@univ-brest.fr (S.T.); \\ Tel.: +34-963-544-423 (C.J.G.-G.); +33-298-016-146 (S.T.)
}

check for updates

Citation: Cuza, E.; Benmansour, S.;

Cosquer, N.; Conan, F.;

Gómez-García, C.J.; Triki, S.

Solvent-Induced Hysteresis Loop in

Anionic Spin Crossover (SCO)

Isomorph Complexes.

Magnetochemistry 2021, 7, 75.

https://doi.org/10.3390/

magnetochemistry7060075

Academic Editor: Marius Andruh

Received: 17 April 2021

Accepted: 20 May 2021

Published: 23 May 2021

Publisher's Note: MDPI stays neutral with regard to jurisdictional claims in published maps and institutional affiliations.

Copyright: (c) 2021 by the authors. Licensee MDPI, Basel, Switzerland. This article is an open access article distributed under the terms and conditions of the Creative Commons Attribution (CC BY) license (https:// creativecommons.org/licenses/by/ $4.0 /)$.
Abstract: Reaction of $\mathrm{Fe}(\mathrm{II})$ with the tris-(pyridin-2-yl)ethoxymethane (py 3 C-OEt) tripodal ligand in the presence of the pseudohalide ancillary $\mathrm{NCSe}^{-}\left(\mathrm{E}=\mathrm{S}, \mathrm{Se}, \mathrm{BH}_{3}\right)$ ligand leads to the mononuclear complex $\left[\mathrm{Fe}\left(\mathrm{py}_{3} \mathrm{C}-\mathrm{OEt}\right)_{2}\right]\left[\mathrm{Fe}\left(\mathrm{py}_{3} \mathrm{C}-\mathrm{OEt}\right)(\mathrm{NCSe})_{3}\right]_{2} \cdot 2 \mathrm{CH}_{3} \mathrm{CN}(3)$, which has been characterised as an isomorph of the two previously reported complexes, $\left.\mathrm{Fe}\left(\mathrm{py}_{3} \mathrm{C}-\mathrm{OEt}\right)_{2}\right]\left[\mathrm{Fe}\left(\mathrm{py}_{3} \mathrm{C}-\right.\right.$ $\left.\mathrm{OEt})(\mathrm{NCE})_{3}\right]_{2} \cdot 2 \mathrm{CH}_{3} \mathrm{CN}$, with $\mathrm{E}=\mathrm{S}(\mathbf{1}), \mathrm{BH}_{3}(2)$. X-ray powder diffraction of the three complexes (1-3), associated with the previously reported single crystal structures of $1-2$, revealed a monomeric isomorph structure for 3 , formed by the spin crossover $(\mathrm{SCO})$ anionic $\left[\mathrm{Fe}\left(\mathrm{py}_{3} \mathrm{C}-\mathrm{OEt}\right)(\mathrm{NCSe})_{3}\right]^{-}$ complex, associated with the low spin $(\mathrm{LS})\left[\mathrm{Fe}\left(\mathrm{py}_{3} \mathrm{C}-\mathrm{OEt}\right)_{2}\right]^{2+}$ cationic complex and two solvent acetonitrile molecules. In the $\left[\mathrm{Fe}\left(\mathrm{py}_{3} \mathrm{C}-\mathrm{OEt}\right)_{2}\right]^{2+}$ complex, the metal ion environment involves two $\mathrm{py}_{3} \mathrm{C}-\mathrm{OEt}$ tridentate ligands, while the $\left[\mathrm{Fe}\left(\mathrm{py}_{3} \mathrm{C}-\mathrm{OEt}\right)(\mathrm{NCSe})_{3}\right]^{-}$anion displays a hexacoordinated environment involving three $\mathrm{N}$-donor atoms of one $\mathrm{py}_{3} \mathrm{C}-\mathrm{OEt}$ ligand and three nitrogen atoms arising from the three (NCSe) ${ }^{-}$coligands. The magnetic studies for 3 performed in the temperature range 300-5-400 K, indicated the presence of a two-step SCO transition centred around 170 and $298 \mathrm{~K}$, while when the sample was heated at $400 \mathrm{~K}$ until its complete desolvation, the magnetic behaviour of the high temperature transition $\left(T_{1 / 2}=298 \mathrm{~K}\right)$ shifted to a lower temperature until the two-step behaviour merged with a gradual one-step transition at ca. $216 \mathrm{~K}$.

Keywords: tripodal ligands; pseudohalide coligands; iron complex; spin crossover; magnetic properties

\section{Introduction}

The spin crossover (SCO) materials are by far the most investigated molecular systems among switchable systems during the last decade due to their many possible applications for the development of new generations of electronic devices, such as displays [1-4], memory devices [4-8], and sensors [9-14]. Although the SCO behaviour can be essentially observed in octahedral complexes based on metal ions allowing spin state changes between the low spin (LS) and high spin (HS) states under external stimulus, such as temperature, pressure, light irradiation, or magnetic field, those based on $\mathrm{Fe}(\mathrm{II})$ ion exhibiting $\mathrm{d}^{6}$ electronic configuration remain the most studied systems [15-29]. Nevertheless, such complexes are mostly either cationic or neutral, and the Fe(II) anionic complexes exhibiting SCO behaviour have been relatively scarcely reported [21-29]. Furthermore, the few anionic $S C O$ examples are restricted to only three different systems. The first one is the series $\left[\mathrm{Fe}^{\mathrm{II}} \mathrm{H}_{3} \mathrm{~L}\right]\left[\mathrm{Fe}^{\mathrm{II}} \mathrm{L}\right] \mathrm{X},\left(\mathrm{X}^{-}=\mathrm{AsF}_{6}{ }^{-}, \mathrm{BF}_{4}{ }^{-}, \mathrm{ClO}_{4}{ }^{-}, \mathrm{PF}_{6}{ }^{-}\right.$and $\left.\mathrm{SbF}_{6}{ }^{-}\right)$, based on the ligand tris-(2-((2-methylimidazol-4-yl)methylidene)amino)ethyl) amine $\left(\mathrm{H}_{3} \mathrm{~L}\right)$ and on its deprotonated anionic form $\left(\mathrm{L}^{3-}\right)$ [21]. The second one consists of the trinuclear $\left[\mathrm{Fe}^{\mathrm{II}}{ }_{3}(\mu-\mathrm{L})_{6}\left(\mathrm{H}_{2} \mathrm{O}\right)_{6}\right]^{6-}$ complex involving the 4-(1,2,4-triazol-4-yl)ethanedisulfonate anion 
$\left(\mathrm{L}^{2-}\right)$ [22], which displays a HS-HS-HS to HS-LS-HS transition around room temperature and a large hysteresis loop $(>85 \mathrm{~K})$. The last system concerns the series of mononuclear complexes involving the tris(2-pyridyl)methane (py ${ }_{3} \mathrm{C}-\mathrm{R}, \mathrm{R}=\mathrm{C}_{\mathrm{n}} \mathrm{H}_{2 \mathrm{n}+1}$, aryl group, $\mathrm{O}-\mathrm{C}_{\mathrm{n}} \mathrm{H}_{2 \mathrm{n}+1}$, O-aryl, O-CO- $\mathrm{C}_{n} \mathrm{H}_{2 n+1}$ ), tridentate functionalized ligands (Scheme 1a) [23-29]. Such complexes, of general formula $\left\{\mathrm{A}\left[\mathrm{Fe}\left(\left(\mathrm{py}_{3} \mathrm{C}-\mathrm{R}\right)(\mathrm{NCE})_{3}\right)\right]_{\mathrm{m}}\right\}\left(\mathrm{A}=\left[\left(\mathrm{C}_{\mathrm{n}} \mathrm{H}_{2 \mathrm{n}+1}\right)_{4} \mathrm{~N}\right]^{+},\left[\mathrm{Fe}\left(\mathrm{py}_{3} \mathrm{C}-\mathrm{R}\right)_{2}\right]^{2+}\right.$, $\mathrm{E}=\mathrm{S}$, Se, $\left.\mathrm{BH}_{3}\right)$, are based on the mononuclear $\left[\mathrm{Fe}\left(\left(\mathrm{py}_{3} \mathrm{C}-\mathrm{R}\right)(\mathrm{NCE})_{3}\right)\right]^{-}$anion composed by an $\mathrm{Fe}(\mathrm{II})$ metal centre, one $\mathrm{py}_{3} \mathrm{C}-\mathrm{R}$ tridentate ligand, and three terminal $\mathrm{kN}-\mathrm{SCE}$ linear coligands (Scheme 1b). The different studies, reported essentially by Ishida et al. and some of us [23-29], have concerned the study of different chemical effects, such as those of the cationic counter ion or of the functional group (R) covalently linked to the tripodal $\mathrm{py}_{3} \mathrm{C}$ motif, on the transition temperatures and the cooperativity. More recently, some of us extended such effects to that of crystal packing by designing a series of polymorph complexes [29].

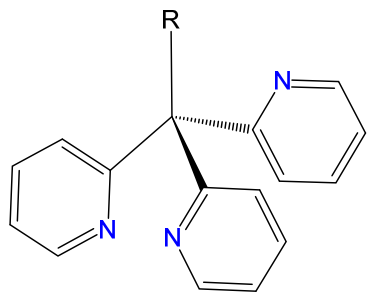

py $_{3} \mathrm{C}-\mathrm{R}, \mathrm{R}=\mathrm{C}_{\mathrm{n}} \mathrm{H}_{2 \mathrm{n}+1}$, aryl group, O- $\mathrm{C}_{\mathrm{n}} \mathrm{H}_{2 \mathrm{n}+1}$, O-aryl, O-CO- $\mathrm{C}_{\mathrm{n}} \mathrm{H}_{2 \mathrm{n}+1}$

(a)

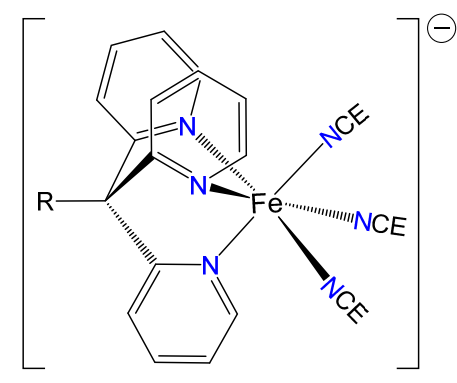

$\left[\mathrm{Fe}\left(\mathrm{py}_{3} \mathrm{C}-\mathrm{R}\right)(\mathrm{NCE}), \mathrm{E}=\mathrm{S}, \mathrm{Se}, \mathrm{BH}_{3}\right.$

(b)

Scheme 1. (a) The tris-(2-pyridyl)methane ( $\left.\mathrm{py}_{3} \mathrm{C}-\mathrm{R}\right)$ ligands and their tridentate coordination mode (b).

In order to determine the effect of the ancillary anionic coligands $\left(\mathrm{NCE}^{-}\right.$with $\mathrm{E}=\mathrm{S}$, $\mathrm{BH}_{3}, \mathrm{Se}$ ) on the transition temperatures and the cooperativity, we have reported recently two isomorphic complexes of general formula, $\left[\mathrm{Fe}\left(\mathrm{py}_{3} \mathrm{C}-\mathrm{OEt}\right)_{2}\right]\left[\mathrm{Fe}\left(\mathrm{py}_{3} \mathrm{C}-\mathrm{OEt}\right)(\mathrm{NCE})_{3}\right]_{2}$. $2 \mathrm{CH}_{3} \mathrm{CN}\left(\mathrm{NCE}^{-}=\mathrm{NCS}^{-}, \mathrm{NCBH}_{3}{ }^{-}\right)$, based on the $\mathrm{SCO}\left[\mathrm{Fe}\left(\mathrm{py}_{3} \mathrm{C}-\mathrm{OEt}\right)(\mathrm{NCE})_{3}\right]^{-}$anion and on the cationic $L S$ complex, $\left[\mathrm{Fe}\left(\mathrm{py}_{3} \mathrm{C}-\mathrm{OEt}\right)_{2}\right]^{2+}$, as counter ion [28]. At the same time, the $\mathrm{NCSe}^{-}$analogue complex $(\mathrm{E}=\mathrm{Se})$, which completes such isomorphic series, has been also prepared. However, this complex, of a presumably chemical formula of $\left[\mathrm{Fe}\left(\mathrm{py}_{3} \mathrm{C}-\right.\right.$ $\left.\mathrm{OEt})_{2}\right]\left[\mathrm{Fe}\left(\mathrm{py}{ }_{3} \mathrm{C}-\mathrm{OEt}\right)(\mathrm{NCSe})_{3}\right]_{2} \cdot 2 \mathrm{CH}_{3} \mathrm{CN}(3)$, could not be obtained as single crystals due to their instability. In addition, while magnetic behaviours of complexes $\mathbf{1}$ and $\mathbf{2}$ remained unchanged in the heating and cooling scan modes, complex 3 showed significant changes during the cooling/warming scan modes. These unexpected observations pushed us to explore in detail the peculiar switching behaviour of this compound. Here, we report the syntheses, structural characterization, infrared spectroscopy, and magnetic properties of the new isomorph $\left[\mathrm{Fe}\left(\mathrm{py}_{3} \mathrm{C}-\mathrm{OEt}\right)_{2}\right]\left[\mathrm{Fe}\left(\mathrm{py}_{3} \mathrm{C}-\mathrm{OEt}\right)(\mathrm{NCSe})_{3}\right]_{2} \cdot 2 \mathrm{CH}_{3} \mathrm{CN}$ (3) exhibiting solventinduced hysteresis loop of $50 \mathrm{~K}$.

\section{Results and Discussion}

\subsection{Syntheses}

The $\mathrm{py}_{3} \mathrm{C}-\mathrm{OEt}$ (tris-(pyridin-2-yl)ethoxymethane) tripodal ligand was prepared as previously described [28-31]. Compound 3 was obtained as a red polycrystalline powder and as single crystals by mixing a solution of $\left[\mathrm{N}\left(\mathrm{C}_{2} \mathrm{H}_{5}\right)_{4}\right](\mathrm{NCSe})$ with a solution of $\mathrm{FeCl}_{2}$ and tris(pyridin-2-yl)ethoxymethane at $-32{ }^{\circ} \mathrm{C}$ (see details in Section 3).

\subsection{Structural Characterization and Magnetic Properties}

In contrast to complexes $\mathbf{1}$ and $\mathbf{2}$, for which the crystal structures were determined using single crystal X-ray diffraction, complex 3, which was expected to be isomorph to 
the structure observed for $\mathbf{1}$ and $\mathbf{2}$, showed poor quality single crystal diffraction patterns that clearly precluded any correct single crystal structural characterization. However, after several attempts at $100 \mathrm{~K}$, we succeeded in collecting some intensities, which led to unit cell parameters depicted in Table S1. Comparison of these parameters to those of the two isomorph complexes $\mathbf{1}$ and $\mathbf{2}$, indicated that the structure of complex $\mathbf{3}$ was isomorphic to complexes $\mathbf{1}$ and $\mathbf{2}$ (Table S1). This conclusion was supported by the experimental X-ray powder diffraction pattern observed for the polycrystalline powder of complex 3 , which was very similar to the one observed for complex $\mathbf{1}$, as well as to the simulated pattern derived from the single crystal structure of complex 1 (Figure 1 and Figure S1).

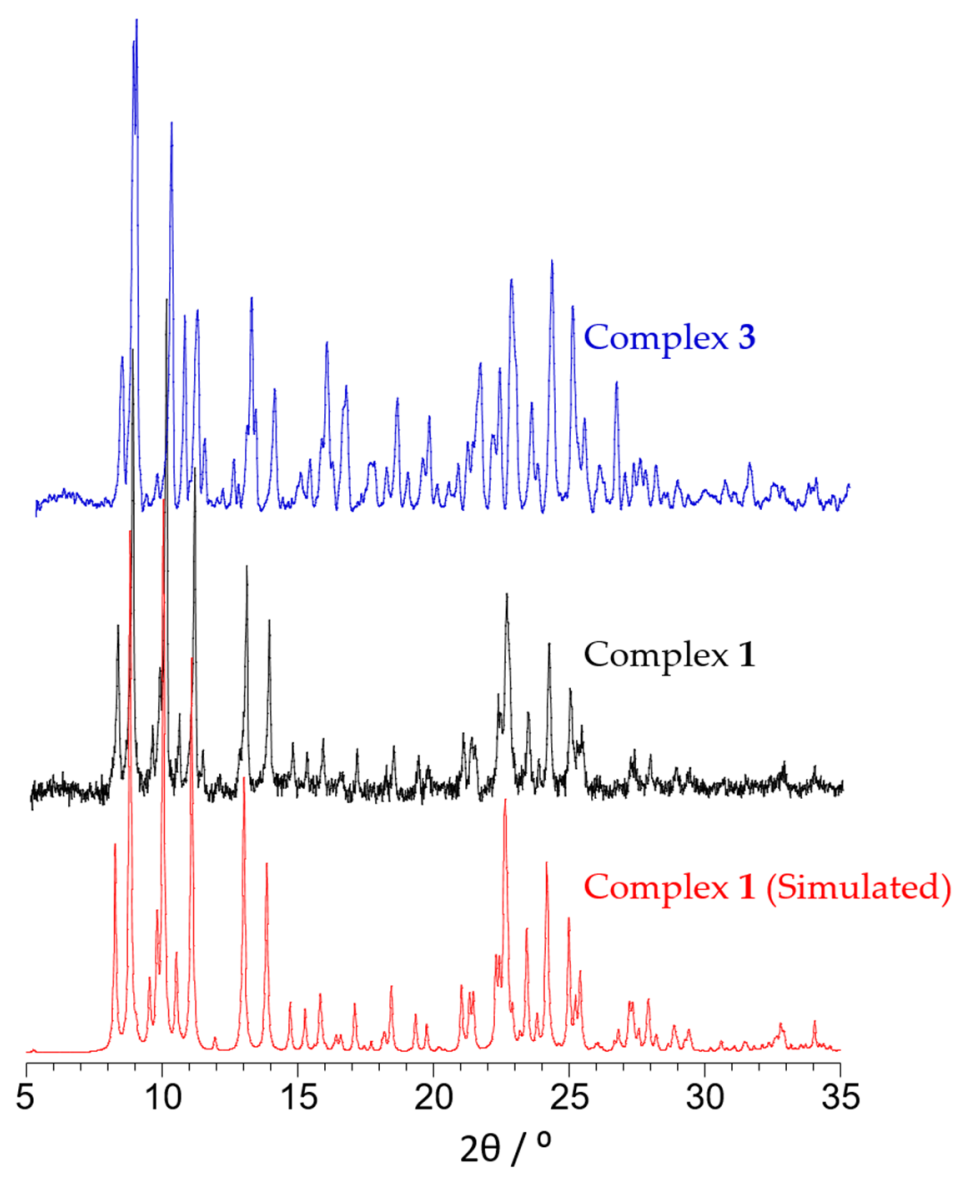

Figure 1. X-ray powder diffraction patterns for $\left[\mathrm{Fe}\left(\mathrm{py}_{3} \mathrm{C}-\mathrm{OEt}\right)_{2}\right]\left[\mathrm{Fe}\left(\mathrm{py}{ }_{3} \mathrm{C}-\mathrm{OEt}\right)(\mathrm{NCE})_{3}\right]_{2} \cdot 2 \mathrm{CH}_{3} \mathrm{CN}$ $(\mathrm{E}=\mathrm{S}(\mathbf{1})$, Se (3)) and the simulated pattern derived from the crystal structure of complex $\mathbf{1}$.

It is also worth mentioning that the elemental analyses of complex 3 agreed with the chemical formula, $\left[\mathrm{Fe}\left(\mathrm{py}_{3} \mathrm{C}-\mathrm{OEt}\right)_{2}\right]\left[\mathrm{Fe}\left(\mathrm{py}_{3} \mathrm{C}-\mathrm{OEt}\right)(\mathrm{NCSe})_{3}\right]_{2} \cdot 2 \mathrm{CH}_{3} \mathrm{CN}$, expected for a complex isomorph to $\mathbf{1}$ and $\mathbf{2}$. Therefore, all the data strongly support that the crystal structure of complex $\mathbf{3}$ is isomorphic to those of complexes $\mathbf{1}$ and $\mathbf{2}$ [28]; and therefore its crystal structure consists of a low spin (LS) $\left[\mathrm{Fe}\left(\mathrm{py}_{3} \mathrm{C}-\mathrm{OEt}\right)_{2}\right]^{2+}$ cationic complex (Figure $2 \mathrm{~b}$ ), an anionic $\left[\mathrm{Fe}\left(\mathrm{py}_{3} \mathrm{C}-\mathrm{OEt}\right)(\mathrm{NCE})_{3}\right]^{-}\left(\mathrm{E}=\mathrm{S}(\mathbf{1}), \mathrm{BH}_{3}(2) \mathrm{Se}(3)\right)$ complex (Figure 2a) and two $\mathrm{CH}_{3} \mathrm{CN}$ solvent molecules. 


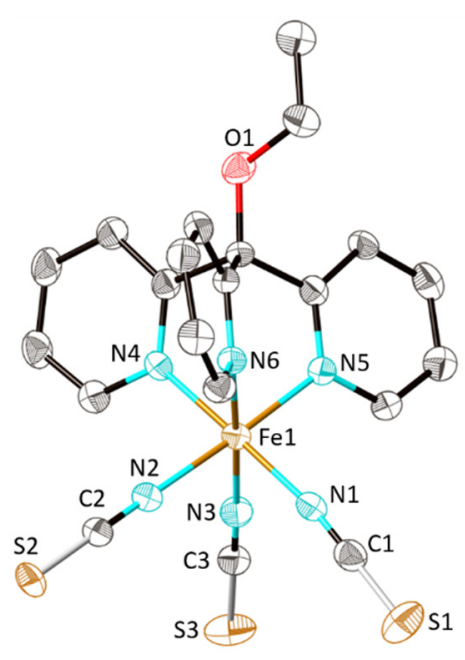

(a)

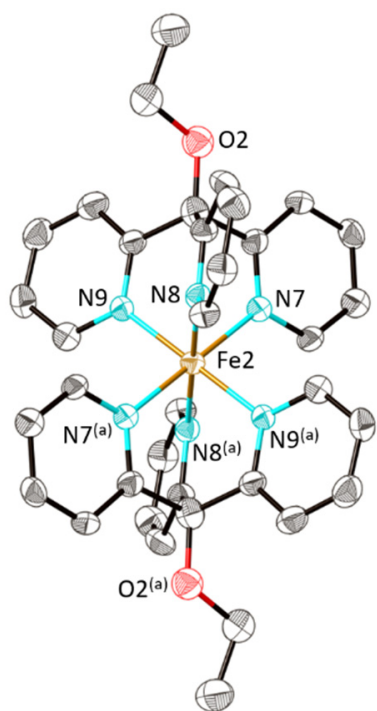

(b)

Figure 2. View of the anionic $\left[\mathrm{Fe}\left(\mathrm{py}_{3} \mathrm{C}-\mathrm{OEt}\right)(\mathrm{NCS})_{3}\right]^{-}(\mathbf{a})$ and of the cationic $\left[\mathrm{Fe}\left(\mathrm{py}{ }_{3} \mathrm{C}-\mathrm{OEt}\right)_{2}\right]^{2+}$ (b) complexes in $\left[\mathrm{Fe}\left(\mathrm{py}_{3} \mathrm{C}-\mathrm{Oet}\right)_{2}\right]\left[\mathrm{Fe}\left(\mathrm{py}_{3} \mathrm{C}-\mathrm{OEt}\right)(\mathrm{NCS})_{3}\right]_{2} \cdot 2 \mathrm{CH}_{3} \mathrm{CN}$ (1) [28]. Codes of equivalent positions: (a) $=-\mathrm{x},-\mathrm{y},-\mathrm{z}$.

As previously described, complex 1 exhibited an incomplete $S C O$ transition $\left(T_{1 / 2}=205 \mathrm{~K}\right)$, while 2 displayed a complete two-step transition at $245 \mathrm{~K}$ and $380 \mathrm{~K}$ (Figure 3). Their magnetic properties were studied in warming and cooling modes (300-2-400-2 K for 1; 300-2-500-2 K for 2), but no significant hysteretic effects or any change due to possible desolvation were detected. Also, irradiation at $10 \mathrm{~K}$ with a green light for several hours revealed no noticeable increase of the thermal variation of the product of the molar magnetic susceptibility times the temperature $\left(\chi_{\mathrm{m}} T\right)$ for both compounds. As for complex $\mathbf{1}$, susceptibility measurements for complex 3 were performed in the 300-5 K and 5-400 K temperature ranges. The thermal variation of the $\chi_{\mathrm{m}} T$ product for the three complexes (1-3) are shown in Figure 3. For compound 3, the $\chi_{\mathrm{m}} T$ value per formula at $400 \mathrm{~K}\left(\approx 6.71 \mathrm{~cm}^{3} \mathrm{~K} \mathrm{~mol}^{-1}\right)$ was in agreement with the value expected for two isolated $\mathrm{Fe}(\mathrm{II})$ ions $(S=2$ and $\mathrm{g} \approx 2.1)$, revealing the presence of two magnetically isolated HS Fe(II) ions [15-29]. On cooling, the $\chi_{\mathrm{m}} T$ value of 3 showed an initial abrupt drop, at around $298 \mathrm{~K}$, reaching a value of ca. $3.40 \mathrm{~cm}^{3} \mathrm{~K} \mathrm{~mol}^{-1}$ at $265 \mathrm{~K}$. On further cooling, we observed a second drop, at around $170 \mathrm{~K}$, to reach a plateau at ca. $0.56 \mathrm{~cm}^{3} \mathrm{~K} \mathrm{~mol}^{-1}$ below $116 \mathrm{~K}$. This low temperature $\chi_{m} T$ value implies the presence of a residual $H S$ fraction of ca. $8 \%$. This behaviour indicates the presence of an incomplete HS to LS two-step transition centred at around 170 and $298 \mathrm{~K}$.

In contrast to isomorphs $\mathbf{1}$ and 2, where the magnetic properties did not show any change after successive cooling and heating scans in the ranges $2-400 \mathrm{~K}$ for $\mathbf{1}$ and $2-500 \mathrm{~K}$ for 2, the two-step behaviour described above for complex 3 (Figure 3) was irreversible due to a gradual desolvation of the sample at $400 \mathrm{~K}$, as previously observed in several solvated systems [32-40]. As a matter of fact, when the sample was maintained at $400 \mathrm{~K}$ until its complete desolvation, the second cycle (400-50-400 K) in 3 produced a shift to lower temperatures for the high temperature step, while the transition temperature of the low temperature step remained unchanged (See Figure 4). Similar trends were observed for the third and fourth cycles, until the fifth cycle where the initial high temperature step merged with the low temperature step (Figure 4), to lead to the gradual one-step transition depicted in Figure 5a. There were no hysteretic effects and the HS fraction of ca. $8 \%$ remained unchanged after the different heating and cooling cycles. 


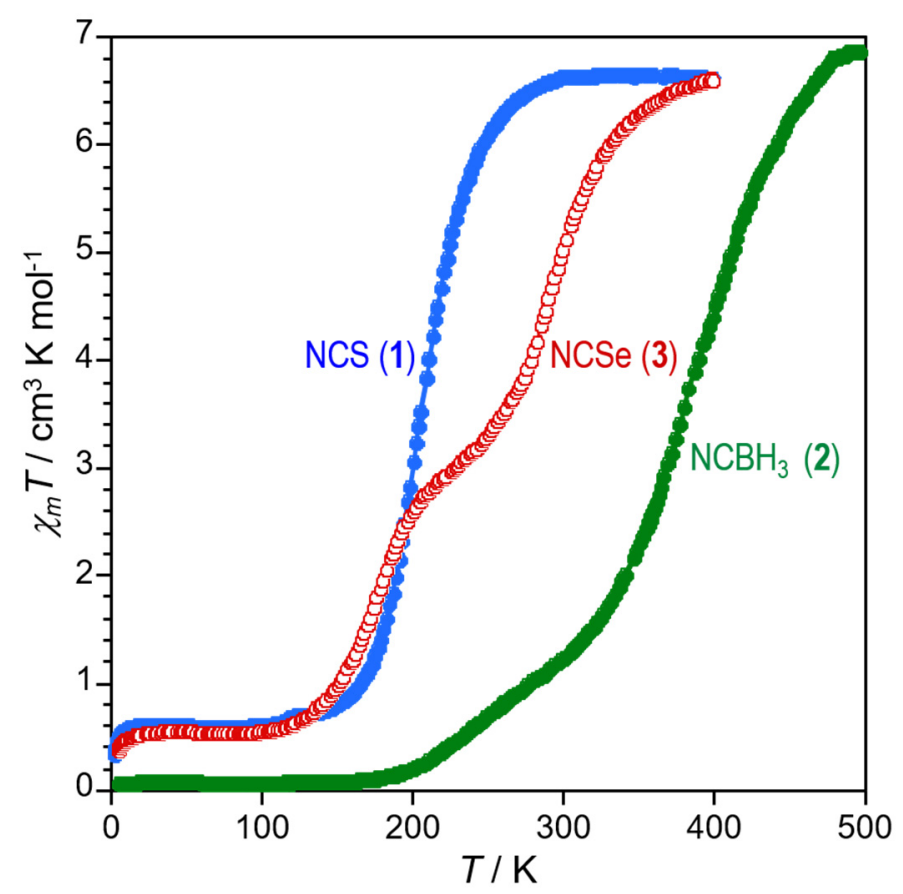

Figure 3. (a) Temperature dependence of the $\chi_{m} T$ product of $\mathbf{1}(\bullet), 2(\bullet)$, and $3(0)$.

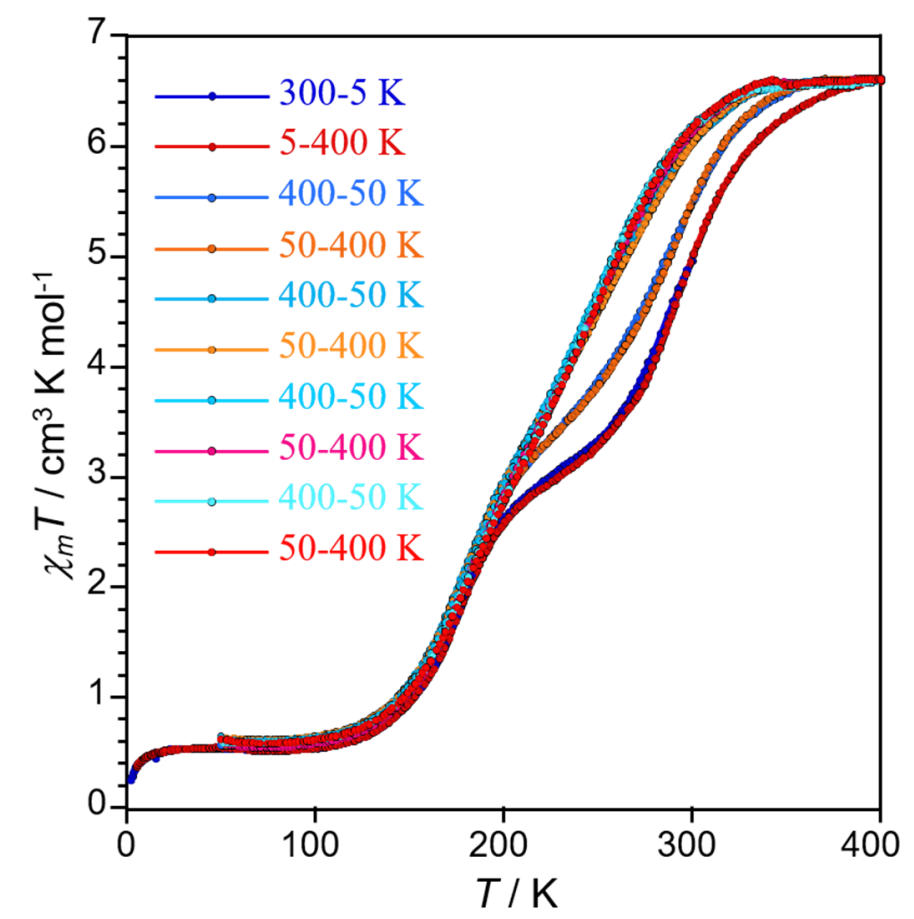

Figure 4. Thermal variation of $\chi_{m} T$ product of a freshly prepared sample of compound 3 for different consecutive heating and cooling scans. 


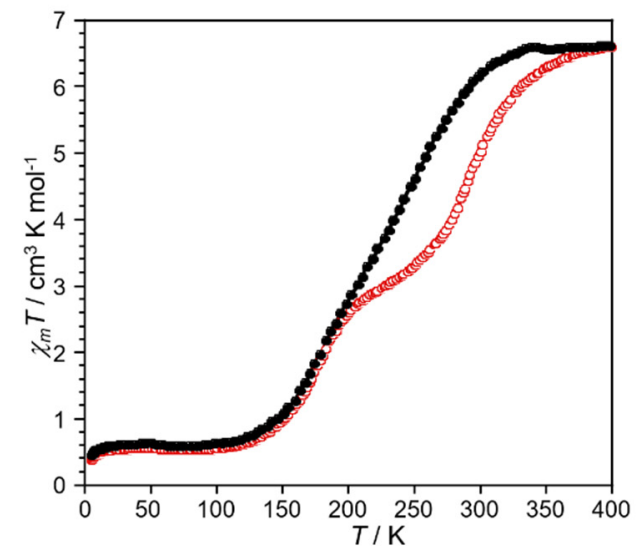

(a)

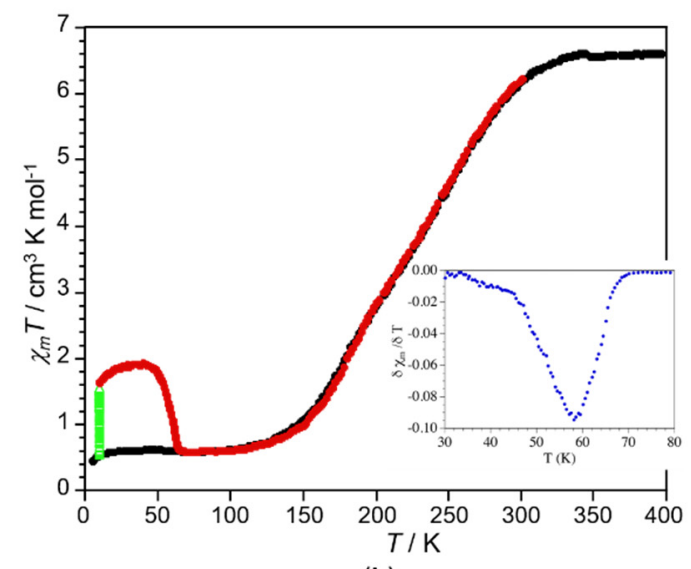

(b)

Figure 5. Magnetic properties of compound 3: (a) thermal evolution of the $\chi_{m} T$ product for the solvated (o) and desolvated $(\bullet)$ samples; (b) thermal evolution of the $\chi_{m} T$ product for the desolvated sample in the dark $(\bullet)$, under $532 \mathrm{~nm}(\Delta)$ light irradiation at $10 \mathrm{~K}$, and the subsequent thermal relaxation $(\bullet)$ in the dark. Inset shows the thermal variation of the derivative of $\chi_{m} T$.

Irradiation of the sample with a green laser $(\lambda=532 \mathrm{~nm})$ at $10 \mathrm{~K}$ produced an increase of the $\chi_{m} T$ product, indicative of the presence of a light-induced excited spin state trapping at low temperatures (LIESST effect). After ca. $4 \mathrm{~h}$, the $\chi_{m} T$ product reached saturation at a value of ca. $1.6 \mathrm{~cm}^{3} \mathrm{~K} \mathrm{~mol}^{-1}$ (Figure S3). This value indicates that around $1 / 3$ of one of the two $\mathrm{LS} \mathrm{Fe}(\mathrm{II})$ centres in the $\left[\mathrm{Fe}\left(\mathrm{py}_{3} \mathrm{C}-\mathrm{OEt}\right)(\mathrm{NCS})_{3}\right]^{-}$anions were excited to the HS state. After switching off the light irradiation, heating the sample further increased the $\chi_{m} T$ value up to ca. $2.0 \mathrm{~cm}^{3} \mathrm{~K} \mathrm{~mol}^{-1}$ (representing ca. $44 \%$ of one of the two $\mathrm{Fe}$ (II) centres). On further heating, the sample relaxed to the $L S$ state at a $T_{\text {LIESST }}$ of ca. $58 \mathrm{~K}$ (Figure $5 \mathrm{~b}$ ).

One of the major points, deserving special attention in regards to the three isomorphic complexes, concerns the origin of the unexpected and singular magnetic behaviour that only occurred for isomorph 3 (see Figures 3 and $5 a$ ). To try to understand the process that occurred at high temperatures, we performed thermogravimetric analysis (TGA) and $\mathrm{X}$-ray powder diffraction on the three isomorphs to know more about the desolvation and solvation processes of this system. Thus, TGA measurements were performed for the three isomorphs, which were heated at $5^{\circ} \mathrm{C} \mathrm{min}^{-1}$, under nitrogen atmosphere, from room temperature to $390 \mathrm{~K}$. In Figure 6, the mass evolution with temperature for the three complexes were gathered, showing clearly that the two isomorphs $\mathbf{1}$ and $\mathbf{2}$ remained stable and retained their solvent molecules up to $390 \mathrm{~K}$, while complex 3 started to lose weight from room temperature and lost $4.37 \%$ of its mass when heated up to $370 \mathrm{~K}$, corresponding to two $\mathrm{CH}_{3} \mathrm{CN}$ solvent molecules per formula unit. These measurements revealed that despite their isomorphic structures, complexes $\mathbf{1}$ and $\mathbf{2}$ retained their crystallization solvent molecules while complex 3 lost them even at moderate temperatures, suggesting that the crystal packing in $\mathbf{3}$ has larger cavities that allow an easy desolvation (see below).

To check for the reversibility of this desolvation process, we performed successive desolvation and resolvation cycles, by heating the solvated sample and by adding two drops of $\mathrm{CH}_{3} \mathrm{CN}$ on the desolvated sample, respectively. After resolvation, magnetic measurements (Figure S4) and X-ray powder diffraction (Figure 7) showed that the sample recovered its original behaviour, supporting the reversibility of the desolvation/resolvation process. 


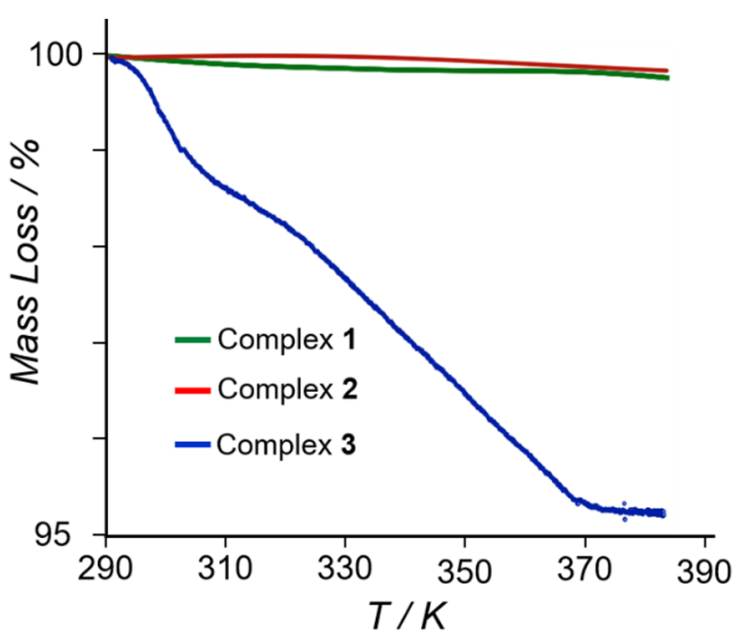

Figure 6. TGA analyses of compounds 1-3.

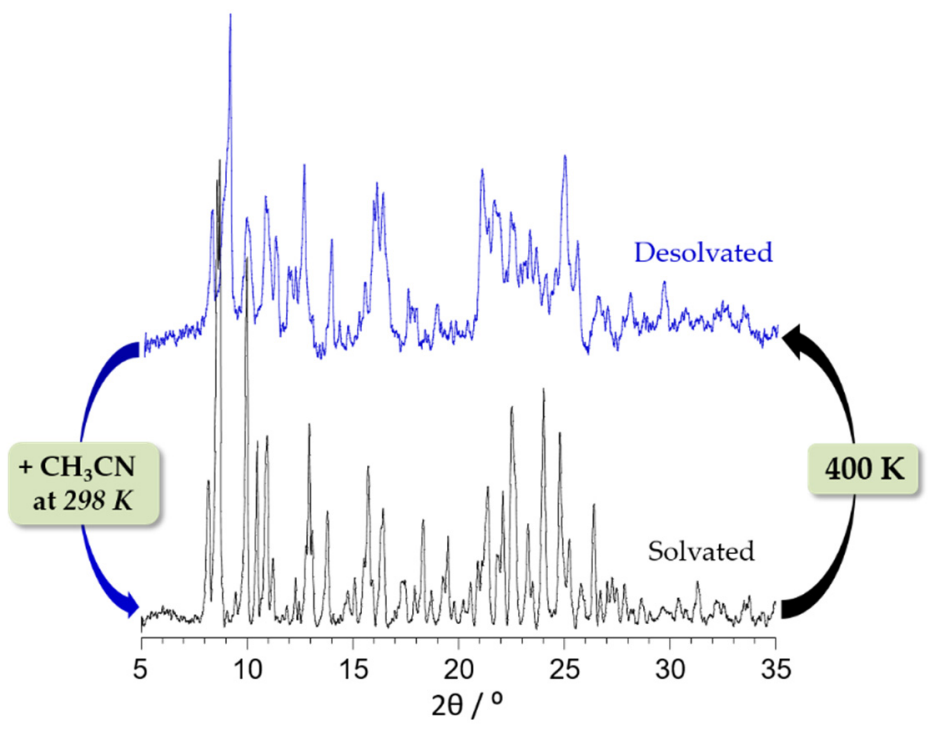

Figure 7. Experimental X-ray powder diffraction patterns of solvated and desolvated samples of 3, confirming the reversibility of the desolvation/resolvation process.

\subsection{Variable Temperature Magnetic Properties and Infrared Spectroscopy}

In order to confirm the $\mathrm{Fe}(\mathrm{II})$ spin state at high and low temperatures and the presence of the incomplete $H S$ to $L S$ transition for 3 (see Figure 3), we measured the infrared spectrum at 100 and $300 \mathrm{~K}$ in the range of the fundamental stretching vibration of the $\mathrm{NCSe}^{-}$units $\left(1975-2130 \mathrm{~cm}^{-1}\right)$, since it has been clearly established that the intensities of these stretching vibrations are very sensitive to the spin state of the Fe(II) metal ion [28,29,41-47]. We thus recorded the infrared spectra for 3 at 350 and $100 \mathrm{~K}$, according to the thermal evolution of the $\chi_{m} T$ product depicted in Figure $5 \mathrm{a}$. The infrared spectra for 3 in the $\mathrm{C} \equiv \mathrm{N}$ frequency region (1975-2130 $\mathrm{cm}^{-1}$ ) at 350 and $100 \mathrm{~K}$ are displayed in Figure 8. At $350 \mathrm{~K}$, two $v_{\mathrm{C} \equiv \mathrm{N}}$ stretching broad bands, characteristic of the $H S$ state, appeared at 2050 and $2075 \mathrm{~cm}^{-1}$, while at $100 \mathrm{~K}$, four strong bands, characteristic of the $L S$ state, appeared at 2044, 2075, 2082, and $2109 \mathrm{~cm}^{-1}$. In agreement with the presence of an $8 \% H S$ fraction at low temperatures (see magnetic section), the three bands observed at 2044, 2075, and $2082 \mathrm{~cm}^{-1}$ can be viewed as resulting from the decrease in intensity of the two broad and strong bands observed for the HS state, while the band observed at a higher frequency $\left(2109 \mathrm{~cm}^{-1}\right)$ appeared as the specific band of the $L S$ state. 


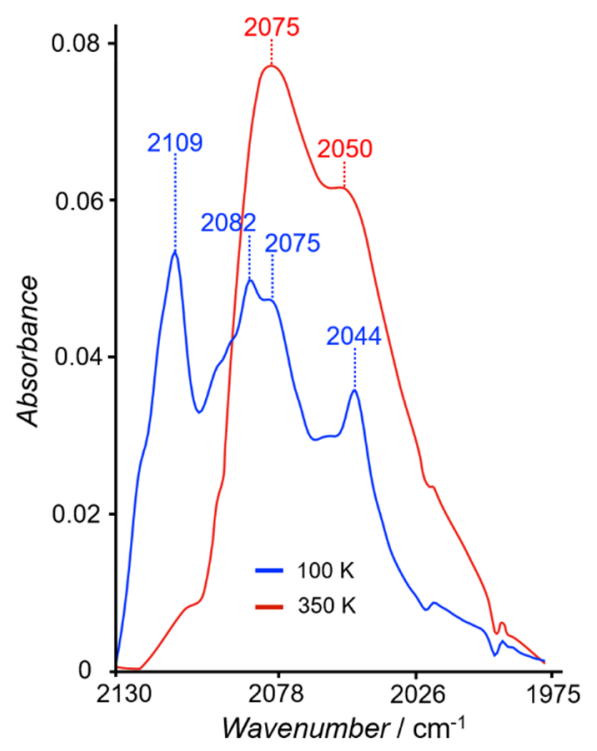

Figure 8. The principal infrared bands in the $1975-2130 \mathrm{~cm}^{-1}$ region for complex 3 at 350 and $100 \mathrm{~K}$.

\subsection{Magneto-Spectroscopic Relationships}

Based on the magnetic behaviours (Figure 5a) and on the main bands that were temperature sensitive (Figure 8) of both solvated and desolvated phases of complex 3, we investigated the thermal evolution of the infrared spectra of the stretching vibration of the $\mathrm{NCSe}^{-}$in the range $1975-2130 \mathrm{~cm}^{-1}$. For both phases (solvated and desolvated), we recorded the infrared spectra in the vicinity of the SCO transitions from 100 to $350 \mathrm{~K}$. First, we recorded the infrared spectra for the freshly prepared complex 3 , heating the sample from 100 to $350 \mathrm{~K}$ to avoid the partial desolvation of the sample (Figure $9 \mathrm{a}$ ). Then, the same sample was heated during one hour at $400 \mathrm{~K}$ to ensure its complete desolvation, and the corresponding infrared spectra were then recorded cooling the sample from 350 to $100 \mathrm{~K}$ (Figure 9b).

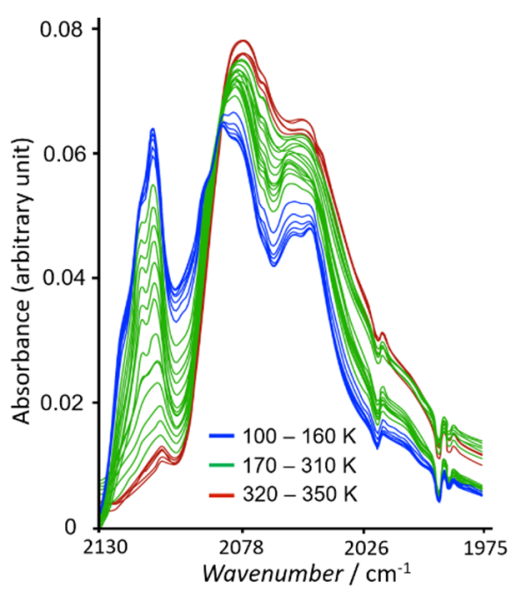

(a)

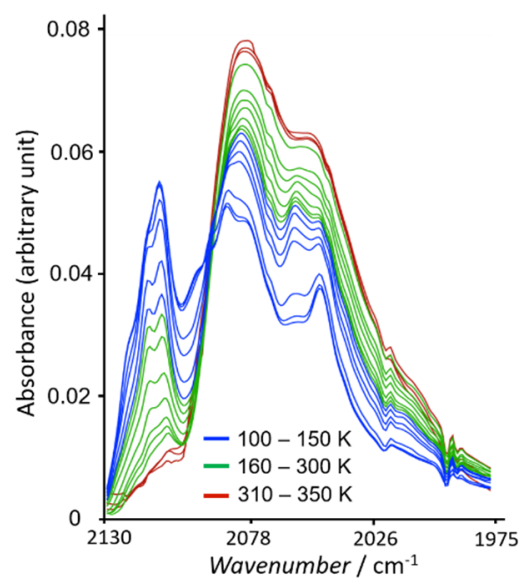

(b)

Figure 9. Temperature dependence of the infrared spectra, in the temperature range 350-100 K, for compound 3: solvated (a) and desolvated (b) samples.

The intensities of the two $v$ (NCSe) broad bands (2050 and $\left.2075 \mathrm{~cm}^{-1}\right)$ attributed to the $H S$ state decreased gradually with decreasing temperature from 350 to $100 \mathrm{~K}$, but persisted even at $100 \mathrm{~K}$, supporting the presence of a fraction of HS Fe(II) centres, as revealed by the magnetic data. In parallel, a new band, characteristic of the $L S$ state, appeared at higher frequencies $\left(2109 \mathrm{~cm}^{-1}\right)$, whose intensity gradually increased with decreasing 
the temperature. However, as can be easily observed in both Figure $9 a, b$, the infrared spectra did not show any clear difference between the infrared band evolutions of the solvated (Figure 9a) and desolvated (Figure 9b) phases of complex 3, as revealed by the magnetic data. Thus, in order to show more clearly this difference and to appreciate, at least qualitatively, the consistency of the experimental infrared data, we correlated the thermal variation of the $\chi_{m} T$ product derived from magnetic study and the thermal evolution of the intensity of the infrared bands. The results, depicted in Figure 10, showed that the intensities of the characteristic infrared bands $\left(2109,2075,2050 \mathrm{~cm}^{-1}\right)$ fit perfectly with the thermal evolution of the $\chi_{m} T$ product, in agreement with the presence of a two-step SCO transition in the solvated sample (Figure 10a) and a gradual one-step SCO behaviour in the desolvated sample (Figure 10b).

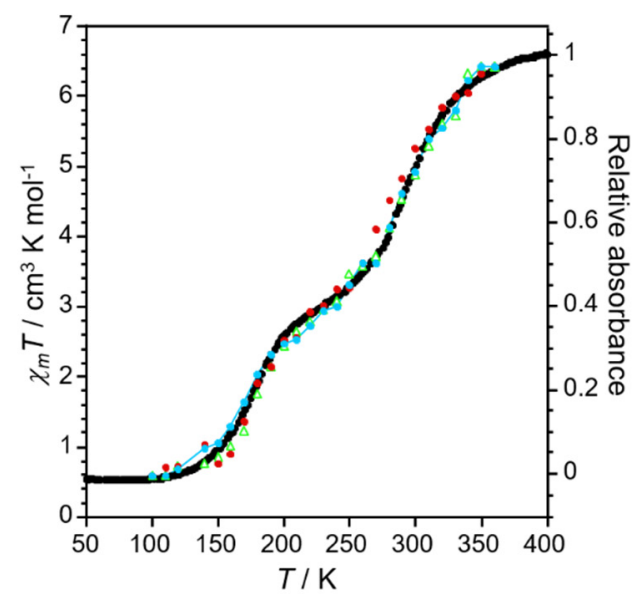

(a)

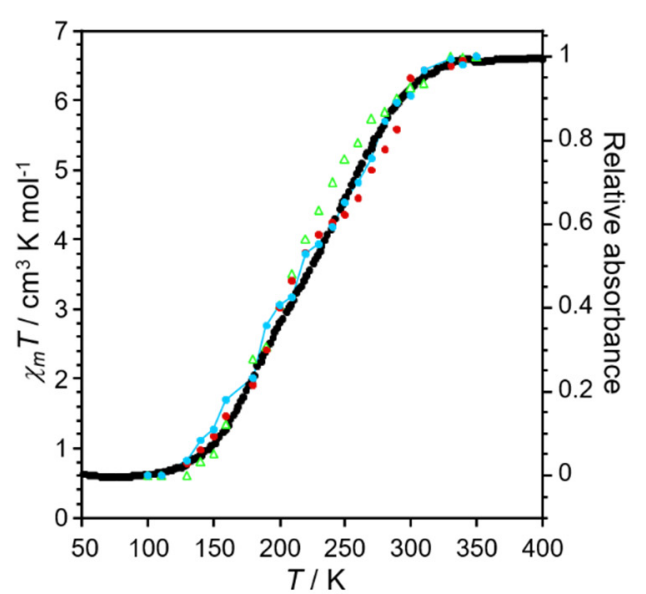

(b)

Figure 10. Temperature dependences of the $\chi_{m} T$ product and of the relative absorbance of the $v(\mathrm{CN})$ bands observed at $2109 \mathrm{~cm}^{-1}(\Delta), 2075 \mathrm{~cm}^{-1}(\bullet)$, and at $2050 \mathrm{~cm}^{-1}(-\bullet-)$, for the solvated (a) and desolvated (b) samples of 3 .

The final question to be answered by this study was why the isomorph based on the $\mathrm{NCSe}^{-}$ligand (complex 3 ) displayed a reversible solvation/desolvation process with $\mathrm{CH}_{3} \mathrm{CN}$ while the two other isomorphs (complexes $\mathbf{1}$ and 2) retained the solvent molecules at temperatures exceeding $390 \mathrm{~K}$. The answer could only come from the crystal packing of this triad of isomorphs. Indeed, examination of the crystal packing revealed that the $\mathrm{CH}_{3} \mathrm{CN}$ solvent molecules are located in tetragonal-like channels running along the [010] direction, which are generated by eclipsed stacks of the -Fe-NCE ... Fe ... ECN-Fe-NCE ... Fe- metallacycles (see Figure 11). Even though the three isomorphs display, as expected, similar crystal packing, the fact that they differ by the nature of the $\mathrm{NCE}^{-}$ancillary ligands $\left(\mathrm{E}=\mathrm{S}(1), \mathrm{BH}_{3}(2)\right.$, Se (3)), induces strong differences in the sizes of the metallacycles, due to the different lengths of the three linear anions (the N-E distance increases from $2.72 \AA$ for $\mathrm{E}=\mathrm{BH}_{3}$, to $2.80 \AA$ for $\mathrm{E}=\mathrm{S}$ and $2.94 \AA$ for $\mathrm{E}=\mathrm{Se}$ ). The largest tetragonal-like channels are expected to be those of the isomorph with the longest ancillary linear ligand (i.e., compound 3). Unfortunately, this difference could not be quantified due to the lack of single crystal structural data of complex 3 . However, in order to provide a reasonable estimation of the effect of the $\mathrm{NCE}^{-}$ligands on the size of the metallacycles, we have calculated the relative increase of their dimensions when passing from complex $\mathbf{2}$ to complex $\mathbf{1}$ (see Figure 11 and Table 1 with the different $\mathrm{Fe} \cdots \mathrm{Fe}$ distances $\left(\mathrm{d}_{1}-\mathrm{d}_{4}\right)$ determining the size of the channels). 


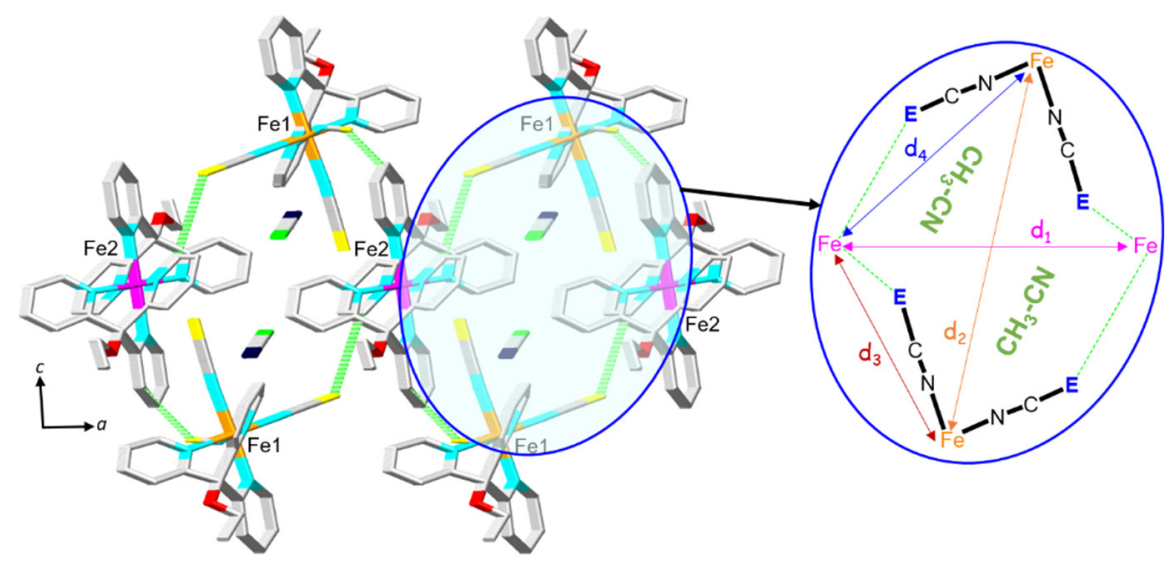

Figure 11. Structure and dimensions of the tetragonal-like channels where the $\mathrm{CH}_{3} \mathrm{CN}$ molecules are located in compounds $\mathbf{1}-\mathbf{3}$.

Table 1. Relative increase Fe $\cdots$ Fe distances $\left(d_{1}\right.$ and $\left.d_{2}\right)$ as function of the nature of the $\mathrm{NCE}^{-}$ancillary ligands $\left(\mathrm{d}_{\mathrm{N}} \ldots . \mathrm{E}\right)$ in the two isomorphs $\mathbf{1}$ and 2.

\begin{tabular}{cccc}
\hline & $\mathbf{2}\left(\mathbf{E}=\mathbf{B H}_{3}\right)$ & $\mathbf{1}(\mathbf{E}=\mathbf{S})$ & $\mathbf{3}(\mathbf{E}=\mathbf{S e})$ \\
\hline $\mathrm{d}_{\mathrm{N}} \ldots$..E (relative increase) & $2.72 \AA$ & $2.80 \AA(+2.9 \%)$ & $2.94 \AA(+8.1 \%)$ \\
T/Spin State & $200 \mathrm{~K} / L S$ & $100 \mathrm{~K} / L S$ & - \\
$\mathrm{d}_{1}$ (relative increase) & 12.757 & $14.774 \AA(+15.8 \%)$ & - \\
$\mathrm{d}_{2}$ (relative increase) & $11.683 \AA$ & $12.653 \AA(+8.3 \%)$ & - \\
$\mathrm{d}_{3}$ (relative increase) & $8.146 \AA$ & $10.481 \AA(+28.6 \%)$ & - \\
$\mathrm{d}_{4}$ (relative decrease) & $9.125 \AA$ & $8.907 \AA(-2.4 \%)$ & - \\
\hline
\end{tabular}

As can be seen in Table 1, when passing from complex 2 (with $\mathrm{NCBH}_{3}{ }^{-}$and $\mathrm{N} \cdots \mathrm{B}$ distance of $2.72 \AA$ ) to complex $\mathbf{1}$ (with $\mathrm{NCS}^{-}$and N...S distance of $2.80 \AA$ ), there is an increase of $+2.9 \%$ in the size of the anion, which led to increases in the Fe $\cdots$ Fe distances in the metallacycle of up to $28.6 \%$ (see $\mathrm{d}_{1}$ to $\mathrm{d}_{4}$ in Table 1 ). Therefore, if we consider complex 3 based on the $\mathrm{NCSe}^{-}$linear ligand, which corresponds to the biggest linear anion (with $\mathrm{N}$...Se distance of $2.94 \AA$ ), the expected metallacycle should be significantly larger than those observed for the isomorphs $\mathbf{1}$ and $\mathbf{2}$. These observations explain clearly why complex 3 involves larger tetragonal-like channels, allowing the easy and reversible solvation and desolvation processes.

\section{Experimental Section}

\subsection{Starting Materials}

All starting reagents and solvents were purchased and used as received. The tris(pyridin-2-yl)ethoxymethane $\left(\mathrm{py}_{3} \mathrm{C}-\mathrm{OEt}\right.$ ) ligand was prepared under nitrogen atmosphere as described previously [28-31].

\subsection{Synthesis of $\left[\mathrm{Fe}\left(\mathrm{py}_{3} \mathrm{C}-\mathrm{OEt}\right)_{2}\right]\left[\mathrm{Fe}\left(\mathrm{py}_{3} \mathrm{C}-\mathrm{OEt}\right)(\mathrm{NCSe})_{3}\right]_{2} \cdot 2 \mathrm{CH}_{3} \mathrm{CN}$ (3)}

Tris-(pyridin-2-yl)ethoxymethane ( $50.0 \mathrm{mg}, 0.17 \mathrm{mmol})$ and $\mathrm{FeCl}_{2}(20.0 \mathrm{mg}, 0.16 \mathrm{mmol})$ were dissolved in methanol $(5 \mathrm{~mL})$ in the presence of a few $\mathrm{mg}$ of ascorbic acid. The mixture was stirred at room temperature for $15 \mathrm{~min}$. To the resulting solution was added a solution of acetonitrile $(5 \mathrm{~mL})$ containing the $\left[\left(\mathrm{C}_{2} \mathrm{H}_{5}\right)_{4} \mathrm{~N}\right] \mathrm{NCSe}$ salt $(162 \mathrm{mg}, 0.69 \mathrm{mmol})$. After $30 \mathrm{~min}$ stirring, the resulting solution was filtered and quickly cooled at $-32{ }^{\circ} \mathrm{C}$. After three days, the bright red polycristalline powder of (3) as well as a few red single crystals were obtained. Anal. Calcd. (\%) for $\left[\mathrm{Fe}\left(\mathrm{py}_{3} \mathrm{C}-\mathrm{OEt}\right)_{2}\right]\left[\mathrm{Fe}\left(\mathrm{py}_{3} \mathrm{C}-\mathrm{OEt}\right)(\mathrm{NCSe})_{3}\right]_{2} \cdot 2 \mathrm{CH}_{3} \mathrm{CN}$ $\left(\mathrm{C}_{82} \mathrm{H}_{74} \mathrm{Fe}_{3} \mathrm{~N}_{20} \mathrm{O}_{4} \mathrm{Se}_{6}\right)$ 3: $\mathrm{C}, 48.2 ; \mathrm{H}, 3.7 ; \mathrm{N}, 13.7$; found (\%): C, 47.9; $\mathrm{H}, 3.8 ; \mathrm{N}, 14.0$. IR data $\left(\mathrm{v} / \mathrm{cm}^{-1}\right)$ for the freshly filtered sample (powder and single crystals, Figure S5): $410(\mathrm{w})$, $423(\mathrm{w}), 477(\mathrm{w}), 500(\mathrm{w}), 513(\mathrm{w}), 530(\mathrm{w}), 659(\mathrm{~m}), 726(\mathrm{w}), 758(\mathrm{w}), 886(\mathrm{w}), 1011(\mathrm{~m}), 1086$ 
(w), $1108(\mathrm{~m}), 1143(\mathrm{~m}), 1205(\mathrm{w}), 1252(\mathrm{w}), 1291(\mathrm{w}), 1389(\mathrm{w}), 1434(\mathrm{~m}), 1462(\mathrm{~s}), 1593(\mathrm{~m})$, 2060 (s), 2244 (w), 2871 (w), 2901 (w), $2972.11(w), 3076(w), 3442$ (br).

\subsection{Characterization of the Materials}

Infrared spectra of complex 3 were performed using a platinum ATR Vertex 70 BRUKER spectrometer with variable temperature cell holder (VT Cell Holder typer P/N GS21525). ${ }^{1} \mathrm{H}$ and ${ }^{13} \mathrm{C}$ NMR spectra were performed using BRUKER DRX $300 \mathrm{MHz}$, Advance $400 \mathrm{MHz}$ and Advance III HD $500 \mathrm{MHz}$ equipment. TGA measurements were performed on ATG-LabsysTM, Setaram (see details in Supplementary Information).

\subsection{Magnetic Measurements}

Magnetic susceptibility measurements were performed using a Quantum Design MPMS-XL-5 SQUID susceptometer (San Diego, CA, USA). The susceptibility data were corrected for the diamagnetic contributions using Pascal's constant tables [48]. The photomagnetic studies were performed by irradiating the sample at $10 \mathrm{~K}$ with a green Diode Pumped Solid State Laser DPSS-532-20 from Chylas (see details in Supplementary Information).

\section{Conclusions}

We have shown that the compound $\left[\mathrm{Fe}\left(\mathrm{py}_{3} \mathrm{C}-\mathrm{OEt}\right)_{2}\right]\left[\mathrm{Fe}\left(\mathrm{py}_{3} \mathrm{C}-\mathrm{OEt}\right)(\mathrm{NCSe})_{3}\right]_{2} \cdot 2 \mathrm{CH}_{3} \mathrm{CN}$ (3), based on the $\left[\mathrm{Fe}\left(\mathrm{py}_{3} \mathrm{C}-\mathrm{OEt}\right)_{2}\right]^{2+} \mathrm{LS}$ cation and the $\mathrm{SCO}\left[\mathrm{Fe}\left(\mathrm{py}_{3} \mathrm{C}-\mathrm{OEt}\right)(\mathrm{NCSe})_{3}\right]^{-}$anion, displays a reversible desolvation process that affects the $S C O$ behaviour. This compound has been prepared as a polycrystalline powder and as single crystals using a similar proto$\mathrm{col}$ to that used previously for the syntheses of the two isomorphic complexes $\left[\mathrm{Fe}\left(\mathrm{py}_{3} \mathrm{C}\right.\right.$ $\left.\mathrm{OEt})_{2}\right]\left[\mathrm{Fe}\left(\mathrm{py}_{3} \mathrm{C}-\mathrm{OEt}\right)(\mathrm{NCE})_{3}\right]_{2} \cdot 2 \mathrm{CH}_{3} \mathrm{CN}\left(\mathrm{E}=\mathrm{S}(\mathbf{1}), \mathrm{BH}_{3}(2)\right)$ based on the two ancillary linear ligands $\mathrm{NCS}^{-}$and $\mathrm{NCBH}_{3}{ }^{-}$[28]. Despite being obtained in the form of prismatic-shaped single crystals, complex 3 could not be characterized by X-ray single crystal diffraction, because of the low stability of its single crystals, in contrast to complexes $\mathbf{1}$ and $\mathbf{2}$, which have been structurally characterized. However, combined X-ray powder diffraction, infrared spectra, and CHN elemental analyses clearly revealed that complex 3 exhibits an isomorphic structure to those of complexes $\mathbf{1}$ and 2. TGA analyses performed on the single crystal samples of the three isomorphs revealed clearly that the two isomorphs $\mathbf{1}$ and $\mathbf{2}$, for which the corresponding single crystals are stable, retained their solvent molecules up to $390 \mathrm{~K}$, while complex 3 began to lose its $\mathrm{CH}_{3} \mathrm{CN}$ solvent molecules from room temperature. The magnetic studies for 3 performed in cooling and heating scans in the temperature ranges $300-5 \mathrm{~K}$ and $5-400 \mathrm{~K}$, respectively, indicated the presence of an incomplete $H S$ to LS two-step like transition centred around 170 and $298 \mathrm{~K}$, while when the sample was heated at $400 \mathrm{~K}$ until its complete desolvation, the magnetic behaviour of the high temperature transition $\left(T_{1 / 2}=298 \mathrm{~K}\right)$ shifted to a lower temperature until the two-step behaviour merged with a gradual one-step transition at ca. $216 \mathrm{~K}$. Such behaviour, which can be viewed as a solvent-induced hysteresis loop of $50 \mathrm{~K}$ [41-47], was confirmed by infrared spectra recorded in the vicinity of the SCO transition for both solvated and desolvated samples. Furthermore, successive desolvation and solvation cycles, tracked by SQUID measurements and X-ray powder diffraction, showed that the desolvation process is fully reversible. As shown by the TGA analysis, compound 3 exhibited a different magnetic behaviour due to its easy desolvation and solvation process, in contrast to the two other isomorphs, which retained their solvent molecule up to $390 \mathrm{~K}$, despite their isomorphic structures. This unexpected behaviour was elucidated by careful examination of the crystal packing of these isomorph complexes, which clearly revealed that the solvent molecules are located in tetragonal-like channels generated by the eclipsed stacks of the "Fe-NCE ... Fe ... ECN-Fe-NCE ... Fe-" metallacycles. Therefore, the isomorph based on the bigger $\mathrm{NCSe}^{-}$ancillary ligand, should display the larger tetragonal-like channels, allowing easier solvation and desolvation as observed in isomorph 3. 
Supplementary Materials: The following are available online at https://www.mdpi.com/article/10 $.3390 /$ magnetochemistry7060075/s1, Table S1: Crystal data of $\left[\mathrm{Fe}\left(\mathrm{py}_{3} \mathrm{C}-\mathrm{OEt}\right)_{2}\right]\left[\mathrm{Fe}\left(\mathrm{py}_{3} \mathrm{C}-\mathrm{OEt}\right)(\mathrm{NCE})_{3}\right]_{2}$. $2 \mathrm{CH}_{3} \mathrm{CN}\left(\mathrm{E}=\mathrm{S}(\mathbf{1}), \mathrm{BH}_{3}(2)\right.$, Se (3)), Figure S1: Experimental and simulated XRPD patterns for compounds 1 and 2, and experimental one for complex 3, Figure S2: Thermal variation of $\chi_{m}$ of a freshly prepared sample of compound 3 for different consecutive heating and cooling scans, Figure S3: Time dependence of $\chi_{m} T$ at $10 \mathrm{~K}$ for compound 3 under laser irradiation with green light $(\lambda=532 \mathrm{~nm}$, switched on at time ca. $10 \mathrm{~min}$ ), Figure S4: Different heating and cooling scans of the $\chi_{m} T$ product performed on the de-solvated compound 3 after re-solvation with two drops of $\mathrm{CH}_{3} \mathrm{CN}$, Figure S5: IR spectra of single crystals and polycrystalline powder of complex 3.

Author Contributions: E.C. performed the chemical syntheses (ligand and the complex) under supervision of S.T. and F.C., and recorded and analysed the infrared spectra under supervision of S.T. and N.C.; F.C. interpreted the NMR spectra; S.B. performed the X-ray powder diffraction; C.J.G.-G. performed and interpreted the magnetic measurements; S.T. supervised the experimental work and wrote the manuscript on which all the authors have contributed. All authors have read and agreed to the published version of the manuscript.

Funding: This research was funded by "Mission pour les Initiatives Transverses et Interdisciplinaires (MITI, CNRS)", Mol-CoSM ANR Project N ${ }^{\circ}$ ANR-20-CE07-0028-01 the "Université de Brest" (IBSAM institute), the Région Bretagne (EC), the Generalidad Valenciana (Prometeo2019/076 project) and the Spanish MINECO (Project CTQ2017-87201-P AEI/FEDER, EU).

Institutional Review Board Statement: Not applicable.

Informed Consent Statement: Not applicable.

Data Availability Statement: Data is contained within the article or Supplementary Material.

Conflicts of Interest: The authors declare no conflict of interest.

\section{References}

1. Cobo, S.; Molnár, G.; Real, J.-A.; Bousseksou, A. Multilayer Sequential Assembly of Thin Films That Display Room-Temperature Spin Crossover with Hysteresis. Angew. Chem. Int. Ed. 2006, 45, 5786-5789. [CrossRef]

2. Kahn, O.; Martinez, C.J. Spin-transition polymers: From molecular materials toward memory devices. Science 1998, 279 , 44-48. [CrossRef]

3. Kumar, K.S.; Ruben, M. Sublimable Spin-Crossover Complexes: From Spin-State Switching to Molecular Devices. Angew. Chem. Int. Ed. 2021, 60, 7502-7521. [CrossRef]

4. Murray, K.S.; Kepert, C.J. Cooperativity in Spin Crossover Systems: Memory, Magnetism and Microporosity. In Spin Crossover in Transition Metal Compounds I; Gütlich, P., Goodwin, H.A., Eds.; Topics in Current Chemistry; Springer: Berlin/Heidelberg, Germany, 2004; Volume 233, pp. 195-228.

5. Létard, J.-F.; Guionneau, P.; Goux-Capes, L. Towards Spin Crossover Applications. In Spin Crossover in Transition Metal Compounds III; Gütlich, P., Goodwin, H.A., Eds.; Topics in Current Chemistry; Springer: Berlin/Heidelberg, Germany, 2004; Volume 235, pp. 221-249.

6. Bousseksou, A.; Molnar, G.; Salmon, L.; Nicolazzi, W. Molecular spin crossover phenomenon: Recent achievements and prospects. Chem. Soc. Rev. 2011, 40, 3313-3335. [CrossRef] [PubMed]

7. Rueckes, T.; Kim, K.; Joselevich, E.; Tseng, G.Y.; Cheung, C.-L.; Lieber, C.M. Carbon Nanotube-Based Nonvolatile Random Access Memory for Molecular Computing. Science 2000, 289, 94-97. [CrossRef]

8. Galet, A.; Gaspar, A.B.; Carmen Muñoz, M.; Bukin, G.V.; Levchenko, G.; Real, J.-A. Tunable Bistability in a Three-Dimensional Spin-Crossover Sensory- and Memory-Functional Material. Adv. Mater. 2005, 17, 2949-2953. [CrossRef]

9. Bartual-Murgui, C.; Akou, A.; Thibault, C.; Molnar, G.; Vieu, C.; Salmon, L.; Bousseksou, A. Spin-crossover metal-organic frameworks: Promising materials for designing gas sensors. J. Mater. Chem. C 2015, 3, 1277-1285. [CrossRef]

10. Lapresta-Fernandez, A.; Titos-Padilla, S.; Herrera, J.M.; Salinas-Castillo, A.; Colacio, E.; Capitan-Vallvey, L.F. Photographing the synergy between magnetic and colour properties in spin crossover material $\left[\mathrm{Fe}\left(\mathrm{NH}_{2} \mathrm{trz}\right)_{3}\right]\left(\mathrm{BF}_{4}\right)_{2}$ : A temperature sensor perspective. Chem. Commun. 2013, 49, 288-290. [CrossRef] [PubMed]

11. Linares, J.; Codjovi, E.; Garcia, Y. Pressure and temperature spin crossover sensors with optical detection. Sensors 2012, 12, 4479-4492. [CrossRef] [PubMed]

12. Cuéllar, M.P.; Lapresta-Fernández, A.; Herrera, J.M.; Salinas-Castillo, A.; del Carmen Pegalajar, M.; Titos-Padilla, S.; Colacio, E.; Capitán-Vallvey, L.F. Thermochromic sensor design based on Fe(II) spin crossover/polymers hybrid materials and artificial neural networks as a tool in modelling. Sens. Actuators B 2015, 208, 180-187. [CrossRef]

13. Rodriguez-Jimenez, S.; Feltham, H.L.C.; Brooker, S. Non-Porous Iron(II)-Based Sensor: Crystallographic Insights into a Cycle of Colorful Guest-Induced Topotactic Transformations. Angew. Chem. Int. Ed. 2016, 55, 15067-15071. [CrossRef] 
14. Benaicha, B.; Van Do, K.; Yangui, A.; Pittala, N.; Lusson, A.; Sy, M.; Bouchez, G.; Fourati, H.; Gómez-García, C.J.; Triki, S.; et al. Interplay between Spin-Crossover and Luminescence in a Multifunctional Single Crystal Iron(II) complex: Towards a New Generation of Molecular Sensors. Chem. Sci. 2019, 10, 6791-6798. [CrossRef]

15. Halcrow, M.A. (Ed.) Spin-Crossover Materials, Properties and Applications; John Wiley \& Sons Ltd: Oxford, UK, 2013.

16. Phan, H.; Hrudka, J.J.; Igimbayeva, D.; Lawson Daku, L.M.; Shatruk, M. A Simple Approach for Predicting the Spin State of Homoleptic Fe(II) Tris-diimine Complexes. J. Am. Chem. Soc. 2017, 139, 6437-6447. [CrossRef] [PubMed]

17. Pittala, N.; Thétiot, F.; Charles, C.; Triki, S.; Boukheddaden, K.; Chastanet, G.; Marchivie, M. An unprecedented trinuclear Fe ${ }^{\mathrm{II}}$ triazole-based complex exhibiting a concerted and complete sharp spin transition above room temperature. Chem. Commun. 2017, 53, 8356-8359. [CrossRef] [PubMed]

18. Shatruk, M.; Phan, H.; Chrisostomo, B.A.; Suleimenova, A. Symmetry-breaking structural phase transitions in spin crossover complexes. Coord. Chem. Rev. 2015, 289-290, 62-73. [CrossRef]

19. El Hajj, F.; Sebki, G.; Patinec, V.; Marchivie, M.; Triki, S.; Handel, H.; Yefsah, S. Macrocycle-based spin-crossover materials. Inorg. Chem. 2009, 48, 10416-10423. [CrossRef]

20. Setifi, F.; Milin, E.; Charles, C.; Thétiot, F.; Triki, S.; Gómez-García, C.G. Spin Crossover Iron(II) Coordination Polymer Chains: Syntheses, Structures, and Magnetic Characterizations of $\left[\mathrm{Fe}(\text { aqin })_{2}\left(\mu-\mathrm{M}(\mathrm{CN})_{4}\right)\right](\mathrm{M}=\mathrm{Ni}(\mathrm{II}), \mathrm{Pt}(\mathrm{II})$, aqin $=$ Quinolin-8-amine). Inorg. Chem. 2014, 53, 97-104. [CrossRef] [PubMed]

21. Yamada, M.; Ooidemizu, M.; Ikuta, Y.; Osa, S.; Matsumoto, N.; Iijima, S.; Kojima, M.; Dahan, F.; Tuchagues, J.-P. Interlayer Interaction of Two-Dimensional Layered Spin Crossover Complexes $\left[\mathrm{Fe}^{\mathrm{II}} \mathrm{H}_{3} \mathrm{LMe}\right]\left[\mathrm{Fe}^{\mathrm{II}} \mathrm{LMe}\right] \mathrm{X}\left(\mathrm{X}^{-}=\mathrm{ClO}_{4}{ }^{-}, \mathrm{BF}_{4}{ }^{-}, \mathrm{PF}_{6}{ }^{-}, \mathrm{AsF}_{6}{ }^{-}\right.$, and $\mathrm{SbF}_{6}{ }^{-} ; \mathrm{H}_{3} \mathrm{LMe}=\operatorname{Tris}[2-(((2-m e t h y l i m i d a z o l-4-y l)$ methylidene)amino)ethyl]amine). Inorg. Chem. 2003, 42, 8406-8416. [CrossRef]

22. Gómez, V.; Sáenz de Pipaón, C.; Maldonado-Illescas, P.; Waerenborgh, J.C.; Martin, E.; Benet-Buchholz, J.; Galán-Mascarós, J.-R. Easy Excited-State Trapping and Record High TTIESST in a Spin-Crossover Polyanionic Fe(II) Trimer. J. Am. Chem. Soc. 2015, 137, 11924-11927. [CrossRef] [PubMed]

23. Hirosawa, N.; Oso, Y.; Ishida, T. Spin crossover and light-induced excited spin-state trapping observed for an iron (II) complex chelated with tripodal tetrakis(2-pyridyl) methane. Chem. Lett. 2012, 41, 716-718. [CrossRef]

24. Yamasaki, M.; Ishida, T. Spin-crossover thermal hysteresis and light-induced effect on iron (II) complexes with tripodal tris (2-pyridyl) methanol. Polyhedron 2015, 85, 795-799. [CrossRef]

25. Yamasaki, M.; Ishida, T. Heating-rate dependence of spin-crossover hysteresis observed in an iron (II) complex having tris (2-pyridyl) methanol. J. Mater. Chem. C 2015, 3, 7784-7787. [CrossRef]

26. Ishida, T.; Kaneto, T.; Yamasaki, M. An iron(II) complex tripodally chelated with 1,1,1-tris(pyridine-2-yl)ethane showing roomtemperature spin-crosssover behaviour. Acta Cryst. Sect. C 2016, 72, 797-801. [CrossRef] [PubMed]

27. Kashiro, A.; Some, K.; Kobayashi, Y.; Ishida, T. Iron(II) and 1,1,1-Tris(2-pyridyl)nonadecane Complex Showing an OrderDisorder-Type Structural Transition and Spin-Crossover Synchronized over Both Conformers. Inorg. Chem. 2019, 58, 7672-7676. [CrossRef]

28. Cuza, E.; Benmansour, S.; Cosquer, N.; Conan, F.; Pillet, S.; Gómez-García, C.J.; Triki, S. Spin Cross-Over (SCO) Anionic Fe(II) Complexes Based on the Tripodal Ligand Tris(2-pyridyl)ethoxymethane. Magnetochemistry 2020, 6, 26. [CrossRef]

29. Cuza, E.; Mekuimemba, C.D.; Cosquer, N.; Conan, F.; Pillet, S.; Chastanet, C.; Triki, S. Spin Crossover and High-Spin State in Fe(II) Anionic Polymorphs Based on Tripodal Ligands. Inorg. Chem. 2021, 60, 6536-6549. [CrossRef]

30. White, D.L.; Faller, J.W. Preparation and Reactions of the $\mathrm{C}_{3 \mathrm{v}}$ Ligand Tris(2-pyridyl)methane and Its Derivatives. Inorg. Chem. 1982, 21, 3119-3122. [CrossRef]

31. Jonas, R.T.; Stack, T.D.P. Synthesis and Characterization of a Family of Systematically Varied Tris(2-pyridyl)methoxymethane Ligands: Copper(I) and Copper(II) Complexes. Inorg. Chem. 1998, 37, 6615-6629. [CrossRef]

32. Benmansour, S.; Gómez-Claramunt, P.; Gómez-García, C.G. Effects of water removal on the structure and spin-crossover in an anilato-based compound. J. Appl. Phys. 2021, 129, 123904. [CrossRef]

33. Kulmaczewski, R.; Bamiduro, F.; Shahid, N.; Cespedes, O.; Halcrow, M.A. Structural Transformations and Spin-Crossover in $\left[\mathrm{FeL}_{2}\right]^{2+}$ Salts (L=4-\{tert-Butylsulfanyl\}-2,6-di\{pyrazol-1-yl $\}$ pyridine): The Influence of Bulky Ligand Substituents. Chem. Eur. J. 2021, 27, 2082-2092. [CrossRef]

34. Mondal, D.J.; Roy, S.; Yadav, J.; Zeller, M.; Konar, S. Solvent-Induced Reversible Spin-Crossover in a 3D Hofmann-Type Coordination Polymer and Unusual Enhancement of the Lattice Cooperativity at the Desolvated State. Inorg. Chem. 2020, 59, 13024-13028. [CrossRef] [PubMed]

35. Phonsri, W.; Davies, C.G.; Jameson, G.N.L.; Moubaraki, B.; Murray, K.S. Spin Crossover, Polymorphism and Porosity to Liquid Solvent in Heteroleptic Iron(III) \{Quinolylsalicylaldimine/Thiosemicarbazone-Salicylaldimine\} Complexes. Chem. Eur. J. 2016, 22, 1322-1333. [CrossRef]

36. Lennartson, A.; Southon, P.; Sciortino, N.F.; Kepert, C.J.; Frandsen, C.; Mørup, S.; Piligkos, S.; McKenzie, C. Reversible Guest Binding in a Non-Porous Fe ${ }^{\mathrm{II}}$ Coordination Polymer Host Toggles Spin Crossover. J. Chem. Eur. J. 2015, 21, 16066-16072. [CrossRef] [PubMed]

37. Roberts, T.D.; Tuna, F.; Malkin, T.L.; Kilner, C.A.; Halcrow, M.A. An iron(II) complex exhibiting five anhydrous phases, two of which interconvert by spin-crossover with wide hysteresis. Chem. Sci. 2012, 3, 349-354. [CrossRef] 
38. Clemente-León, M.; Coronado, E.; Giménez-López, M.C.; Romero, F.M. Structural, Thermal, and 52Magnetic Study of Solvation Processes in Spin-Crossover [Fe(bpp $\left.)_{2}\right]\left[\mathrm{Cr}(\mathrm{L})(\mathrm{ox})_{2}\right]_{2} \cdot n \mathrm{H}_{2} \mathrm{O}$ Complexes. Inorg. Chem. 2007, 46, 11266-11276. [CrossRef]

39. Hayami, S.; Gu, Z.-Z.; Yoshiki, H.; Fujishima, A.; Sato, O. Iron(III) Spin-Crossover Compounds with a Wide Apparent Thermal Hysteresis around Room Temperature. J. Am. Chem. Soc. 2001, 123, 11644-11650. [CrossRef]

40. Garcia, Y.; Van Koningsbruggen, P.J.; Codjovi, E.; Lapouyade, R.; Kahn, O.; Rabardel, L. Non-classical FeII spin-crossover behaviour leading to an unprecedented extremely large apparent thermal hysteresis of $270 \mathrm{~K}$ : Application for displays. J. Mater. Chem. 1997, 7, 857-858. [CrossRef]

41. Sorai, M.; Seki, S. Phonon coupled cooperative low-spin ${ }^{1} \mathrm{~A}_{1} \leftrightarrow$ high-spin ${ }^{5} \mathrm{~T}_{2}$ transition in [Fe(phen) 2 (NCS) 2 ] and [Fe(phen $)_{2}(\mathrm{NCSe})_{2}$ ] crystals. J. Phys. Chem. Solids 1974, 35, 555-570. [CrossRef]

42. Brehm, G.; Reiher, M.; Le Guennic, B.; Leibold, M.; Schindler, S.; Heinemann, F.W.; Schneider, S. Investigation of the low-spin to high-spin transition in a novel [Fe(pmea)(NCS $)_{2}$ ] complex by IR and Raman spectroscopy and DFT calculations. J. Raman Spectrosc. 2006, 37, 108-122. [CrossRef]

43. Park, Y.; Jung, Y.M.; Sarker, S.; Lee, J.-J.; Lee, Y.; Lee, K.; Oh, J.J.; Joo, S.-W. Temperature-dependent infrared spectrum of $\left(\mathrm{Bu}_{4} \mathrm{~N}\right)_{2}\left[\mathrm{Ru}(\mathrm{dcbpyH})_{2}(\mathrm{NCS})_{2}\right]$ on nanocrystalline $\mathrm{TiO}_{2}$ surfaces. Solar Energy Mater. Solar Cells 2010, 94, 857-864. [CrossRef]

44. Varma, V.; Fernandes, J.-R. An Infrared Spectroscopic Study of the Low-Spin-High-spin transition in in Fe $\mathrm{Mn}_{1-\mathrm{x}}(\mathrm{Phen})_{2}(\mathrm{NCS})_{2}$ : A Composition-Induced Change in the Order of the Spin-State Transition. Chem. Phys. Let. 1990, 167, 367-370. [CrossRef]

45. Sankar, G.; Thomas, J.M.; Varma, V.; Kulkani, G.U.; Rao, C.N.R. An investigation of the first-order spin-state transition in the $\mathrm{Fe}(\text { phen })_{2}(\mathrm{NCS})_{2}$ EXAFS and infrared spectroscopy. Chem. Phys. Lett. 1996, 251, 79-83. [CrossRef]

46. Smit, E.; de Waal, D.; Heyns, A.M. The spin-transition complexes $\left[\mathrm{Fe}(\mathrm{Htrz})_{3}\right]\left(\mathrm{ClO}_{4}\right)_{2}$ and $\left.\left[\mathrm{Fe}\left(\mathrm{NH}_{2} \operatorname{trz}\right)_{3}\right](\mathrm{ClO})_{2}\right)_{2}$ I. FT-IR spectra of a low pressure and a low temperature phase transition. Mater. Res. Bull. 2000, 35, 1697-1707. [CrossRef]

47. Durand, P.; Pillet, S.; Bendeif, E.-E.; Carteret, C.; Bouazaoui, M.; El Hamzaoui, H.; Capoen, B.; Salmon, L.; Hébert, S.; Ghanbaja, J.; et al. Room temperature bistability with wide thermal hysteresis in a spin crossover silica nanocomposite. J. Mater. Chem. C 2013, 1, 1933-1942. [CrossRef]

48. Bain, G.A.; Berry, J.F. Diamagnetic corrections and Pascal's constants. J. Chem. Educ. 2008, 85, 532-536. [CrossRef] 